\title{
Enhanced UV Direct Photolysis And UV/H2O2 For Oxidation of Triclosan And Ibuprofen In Synthetic Effluent: An Experimental Study
}

\section{Vilson Conrado da Luz}

USP: Universidade de Sao Paulo

Suzana Fatima Bazoti

UFFS: Universidade Federal da Fronteira Sul

Laura Behling

UFFS: Universidade Federal da Fronteira Sul

Clarissa Dalla Rosa

UFFS: Universidade Federal da Fronteira Sul

Gean Delise Leal Pasquali ( $\nabla$ geandelise@uffs.edu.br)

Universidade Federal da Fronteira Sul https://orcid.org/0000-0001-5110-6532

\section{Research Article}

Keywords: Advanced oxidation processes, Kinetics, Photodegradation, PPCP

Posted Date: September 14th, 2021

DOl: https://doi.org/10.21203/rs.3.rs-797699/v1

License: (9) This work is licensed under a Creative Commons Attribution 4.0 International License.

Read Full License 
Vilson Conrado da Luz ${ }^{1}$, Suzana Fatima Bazoti ${ }^{1}$, Laura Behling ${ }^{1,2}$, Clarissa Dalla Rosa ${ }^{1,2}$, Gean Delise Leal

Pasquali $^{1,2 *}$

*Corresponding Author: Gean Delise Leal Pasquali (geandelise@ uffs.edu.br) Phone No.: +55 (54) 3321-7336;

\section{Declarations}

16 Ethics approval and consent to participate: Not applicable

17 Consent for publication: Not applicable

18 Availability of data and materials: All data generated or analysed during this study are included in this published

19 article [and its supplementary information files].

20 Competing interests: The authors declare that they have no competing interests

21 Funding: Federal University of Fronteira Sul (UFFS) was responsible for the laboratory area and the acquisition

22 of reagents and equipment; Rio Grande do Sul State Research Support Foundation (FAPERGS) for the financial

23 support (scientific initiation scholarship n ${ }^{\circ} 368$ /UFFS /2020)

24 Authors' contributions: All authors contributed to the study conception and design. Material preparation, data 25 collection and analysis were performed by Vilson Conrado da Luz, Gean Delise Leal Pasquali, Suzana Fátima 26 Bazoti, Laura Behling and Clarissa Dalla Rosa. The first draft of the manuscript was written by Vilson Conrado da 27 Luz, Suzana Fatima Bazoti and Gean Delise Leal Pasquali, all authors commented on previous versions of the 28 manuscript. All authors read and approved the final manuscript.

29 Acknowledgments: The authors gratefully acknowledge the Rio Grande do Sul State Research Support Foundation 30 (FAPERGS) for the financial support (grant $\mathrm{n}^{\circ} 368$ /UFFS /2020) 
37 This study aimed to evaluate the implementation of an advanced oxidation system based on UV radiation and

$38 \mathrm{UV} / \mathrm{H}_{2} \mathrm{O}_{2}$ for degradation of TCS and IBU in synthetic effluent. The assays occurred in a $2 \mathrm{~L}$ reactor, protected

39 from external light and equipped with a UV lamp $(\lambda=254 \mathrm{~nm})$. The effect of contaminant concentration, fractions

40 of chemical species present, and mineralization were evaluated. In the $\mathrm{UV} / \mathrm{H}_{2} \mathrm{O}_{2}$ system, different concentrations

41 of $\mathrm{H}_{2} \mathrm{O}_{2}$ were studied for oxidation of the contaminants. The kinetic experiments took place between $75-270 \mathrm{~min}$

42 of UV irradiation. The results showed $>99 \%$ oxidation of TCS in the direct photolysis system at pH 9.4 after 12

43 min. The degradation of IBU in the $\mathrm{UV} / \mathrm{H}_{2} \mathrm{O}_{2}$ system, when $10 \mathrm{mg} \mathrm{L}^{-1}$ of $\mathrm{H}_{2} \mathrm{O}_{2}$ was used, obtained $97.39 \%$

44 oxidation. We obtained $k^{\prime}$ values of $0.189 \mathrm{~min}^{-1}$ for TCS when its highest oxidation occurred, and $k^{\prime}$ values of

$450.0219 \mathrm{~min}^{-1}$ for IBU. The system was not able to completely mineralize the contaminants, presenting high values

46 of TOC and COD after treatment, thus suggesting the occurrence of phototransformation.

48 Keywords: Advanced oxidation processes. Kinetics. Photodegradation. PPCP.

\section{Introduction}

Being classified as emerging contaminants, pharmaceutically active compounds, and personal care products (PPCPs) can present serious risks to the environment. The increasing population and life expectancy of people cause PPCPs to be continuously consumed and released into the environment, thus such contaminants need not be persistent in order to compromise ecosystems (Arnold et al. 2013; Rede et al. 2019).

Not only behavioral and longevity changes, but environmental changes are also causing numerous consequences to the environment. An example of this is the effects provided by the COVID-19 pandemic, such as reduced concentrations of pollutant gases (Wang and Su 2020) and improved water quality parameters (Yunus et al. 2020). However, several negative effects have also been noted.

The use of pharmaceuticals and personal care products to treat and prevent COVID-19 has significantly increased the presence of these substances in wastewater treatment plants (Espejo et al. 2020; Bandala et al. 2021; Guidony et al. 2021). These contaminants can be non-prescription drugs that combat common symptoms such as fever, in the case of ibuprofen (Jamerson and Haryadi 2020), and antimicrobial agents widely present in hand sanitizers such as triclosan (Guidony et al. 2021).

Ibuprofen (IBU, (RS)-2-(4-(2 methylpropyl)phenyl)propanoic acid) is a weak organic acid, highly bound to plasma albumin and extensively metabolized and excreted in the form of metabolites and their conjugates, having an elimination half-life of approximately two hours (Hersh and Dionne 2017). After administration, about $15 \%$ of the compound is excreted in the parental form and $26 \%$ and $43 \%$ in the form of hydroxyl-IBU and carboxyIBU metabolites, respectively (Farré, Marinel; Pérez, Sandra; Kantiani, Lina; Barceló 2008). In the natural environment IBU poses several risks, such as oxidative stress in fish (Plhalova et al., 2017), and negative effects of rotifer survival and reproduction (Pérez 2016).

Triclosan (TCS, 5-chloro-2-(2.4-dichlorophenoxy) phenol) is a broad-spectrum antimicrobial agent, and due to its great efficiency, it has been increasingly used in the formulations of soaps, toothpastes, and various skin and oral cosmetic products (Iovino et al. 2019; Gopalakrishnan et al. 2021). TCS is introduced into the natural 
a potential risk because of its ability to inhibit algal growth (Mohan and Balakrishnan 2019), toxic effects on invertebrates (Khatikarn et al. 2018), and increased microbial resistance (Drury et al. 2013), among other effects. Ingested pharmaceuticals are excreted into the environment through animal and human urine and feces (Fang et al. 2012).. About 10-90\% of administered doses of pharmaceutical and personal care products (PPCPs) are excreted from the human body in parent forms, and the remainder as metabolites and/or conjugated forms (Balakrishna et al. 2017).

Due to the wide use of TCS and IBU, these emerging contaminants are detected in natural environments, such as rivers, at concentrations of 3 - $68 \mathrm{ng} \mathrm{L}^{-1}$ (Yang et al. 2015) and $0.59-1.4 \mu \mathrm{L}^{-1}$ (Amos Sibeko et al. 2019), also being found in wastewater treatment plants 443 - $1757 \mathrm{ng} \mathrm{L}^{-1}$ (Mohan and Balakrishnan 2019) and 8612.9 $1607.8 \mathrm{ng} \mathrm{L}^{-1}$ (Kermia et al. 2016). A few of the physicochemical properties of TCS and IBU are presented in Table 1.

Advanced Oxidation Processes (AOPs) is a concept initially proposed by Glaze in 1987. They consist of methods that can be applied to the treatment of various compounds that are difficult to remove, as they chemically destroy numerous contaminants by generating strong oxidizing agents, such as hydroxyl radicals $(\mathrm{HO} \bullet$ ), which can attack and mineralize organic contaminants (Glaze et al. 1987; Coha et al. 2021).

AOPs are considered powerful engineering solutions for processes that usually need to be integrated for the removal of different contaminants, since they reach numerous compounds of different concentrations in the same treatment system (Coha et al. 2021). Among the main AOPs used for degradation of organic substances are Fenton processes, ozonation, electrochemical oxidation, and photochemical processes (Domingues et al. 2021).

Photochemical processes have low secondary pollution rates and low operating costs (Liu et al. 2018; Tan et al. 2021). Such processes are based on the supply of energy through radiation $(E \lambda=h v)$ to a molecule, where the substance absorbs the energy photons and reaches specific levels of excited states, levels sufficient for the excitation of electrons and formation of free radicals that will act on the organic contaminant (Cuerda-Correa et al.

98 2020). In this study, the photochemical processes $\mathrm{UV} / \mathrm{H}_{2} \mathrm{O}_{2}$ and direct $\mathrm{UV}$ photolysis were evaluated as final

99 polishing technology for oxidation of TCS and IBU in synthetic effluent.

Table 1. Physical-chemical properties of TCS and IBU

\begin{tabular}{lll}
\hline Compound & Physical-chemical properties \\
\cline { 1 - 2 } Triclosan
\end{tabular}

102 


\subsection{Reagents}

Triclosan ( $\geq 97.0 \%$ ) and ibuprofen ( $\geq 99.0 \%$ ), used for chromatographic curves, were purchased from

109 Sigma-Aldrich. LC-MS grade $\mathrm{MeOH}$, formic acid (analytical grade) and ultrapure water (> $18 \mathrm{M} \Omega \mathrm{cm}$, Milli-Q-

110 POD) were used for HPLC analyses. Triclosan ( $\geq 97 \%$, Êxodo científica, Brazil), commercial ibuprofen powder

111 (Artesani, Brazil), $\mathrm{NaOH}$ and hydrogen peroxide (analytical grades) were used for the synthetic effluent. $\mathrm{Na}_{2} \mathrm{HPO}_{4}$,

$112 \mathrm{KH}_{2} \mathrm{PO}_{4}, \mathrm{Na}_{2} \mathrm{CO}_{3}, \mathrm{NaHCO}_{3}, \mathrm{CH}_{3} \mathrm{COOH}$ and $\mathrm{C}_{2} \mathrm{H}_{3} \mathrm{NaO}_{2}$ (analytical grades) were used for buffer solutions.

\section{2.2. Quantitative Analyses}

115 Quantitative analyses were performed using high-performance liquid chromatography (LCMS 2020,

116 Shimadzu) with an SPD-M20A photodiode array detector. Separation took place on a C18 column ( $250 \times 4.6 \mathrm{~mm}$;

$1175 \mu \mathrm{m})$ operated at $30^{\circ} \mathrm{C}$, using mobile phase in isocratic mode $(80: 20 \mathrm{MeOH}$ and ultrapure water mixture, acidified

118 with $0.001 \%$ formic acid) with flow rate of $0.8 \mathrm{~mL} \mathrm{~min}^{-1}$, injection volume of $20 \mu \mathrm{L}$, and $25 \mathrm{~min}$ of analysis time.

119 The wavelength was maintained at 200 and $280 \mathrm{~nm}$ for detection of IBU and TCS, respectively. Quantification

120 was done through chromatographic curves updated periodically with standard solutions of TCS and IBU. The

121 chromatographic detection limit was 0.05 and $0.1 \mathrm{mg} \mathrm{L}^{-1}$ for TCS and IBU, respectively.

122 TOC concentration was determined by the difference of total carbon and inorganic carbon using a total

123 organic carbon analyzer (TOC-L CPN, Shimadzu), with values reported as the average of three successive 124 readings.

\subsection{Synthetic effluent}

The stock solution of triclosan uses a methodology adapted from Lu et al. (Lu et al. 2009), being the mass

129 solution. The stock solution of ibuprofen was adapted from Wang et al. 2019), formulated by dissolving the mass 130 of IBU in $0.5 \mathrm{~mL}$ of $\mathrm{MeOH}$, due to the low solubility of the compound in water.

131 The synthetic effluent was made up from the solutions of triclosan and ibuprofen, and the $\mathrm{pH}$ was 132 controlled by $10 \mathrm{mM}$ buffer solutions. Carbonate-bicarbonate buffer was used for $\mathrm{pH}=9.4$, phosphate buffer for $133 \mathrm{pH}=6.0$, and acetate buffer for $\mathrm{pH}=3.6$.

\subsection{Experimental set-up}

The reactor was made of glass with dimensions of $15 \mathrm{~cm} \times 45 \mathrm{~cm} \times 15 \mathrm{~cm}$, with the base established on two magnetic stirrers kept at $120 \mathrm{rpm}$. At the top, a UV lamp (OSRAM Puritec HNS L, Italy) of $38 \mathrm{~cm}$ in length and

$13836 \mathrm{~W}$ of power, average wavelength of $254 \mathrm{~nm}$, and average light intensity of $7800 \mathrm{~cd}$ (Fig. 1). The reactor was 139 installed in a dark room with no light entering from the external environment. 


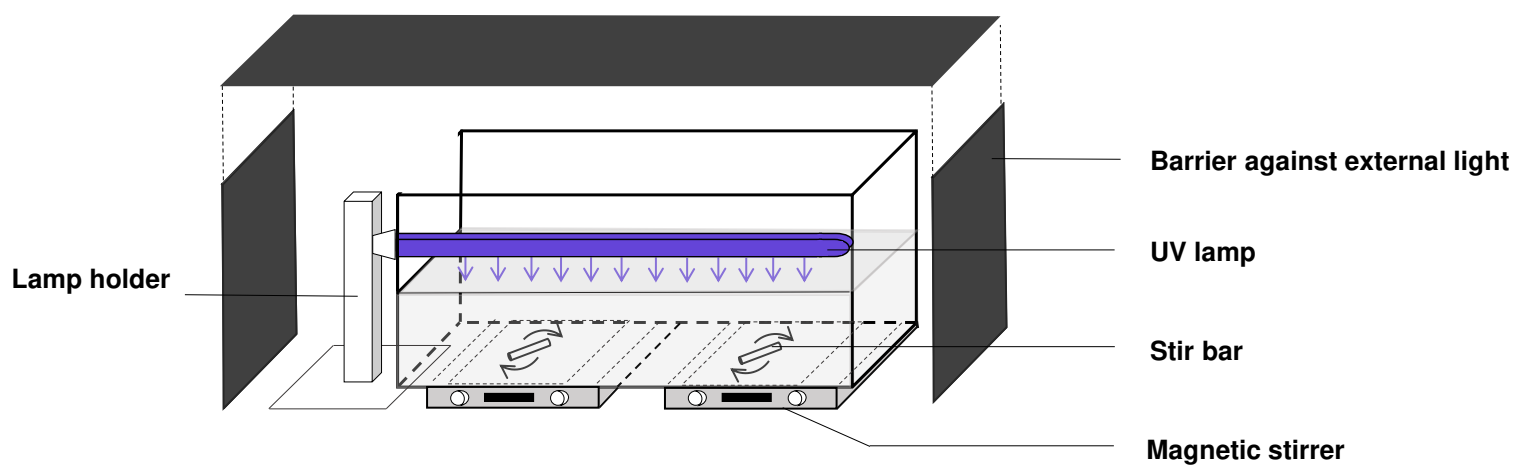

142 Fig. 1. Experimental set-up used for direct UV and $\mathrm{UV} / \mathrm{H}_{2} \mathrm{O}_{2}$ oxidation of IBU and TCS in synthetic effluent.

\subsection{Photo-oxidation experiments}

The reactor operating conditions on the photo-oxidation of IBU and TCS were evaluated as a function of irradiation time $(0-270 \mathrm{~min})$. The direct photolysis experiments occurred by varying the parameters, initial concentration $\left(\mathrm{TCS}_{0}=8.89-17.79 \mathrm{mg} \mathrm{L}^{-1} ; \mathrm{IBU}_{0}=9.90-34.24 \mathrm{mg} \mathrm{L}^{-1}\right)$, and $\mathrm{pH}$ of the solution $(\mathrm{pH}=3.6 ; 6.0$; 9.4). The $\mathrm{UV} / \mathrm{H}_{2} \mathrm{O}_{2}$ system was studied by adding $\mathrm{H}_{2} \mathrm{O}_{2}\left(0-15 \mathrm{mg} \mathrm{L}^{-1}\right)$, keeping the concentrations of IBU and TCS constant $\left(\mathrm{TCS}_{0}=15.46 \mathrm{mg} \mathrm{L}^{-1} ; \mathrm{IBU}_{0}=34.5 \mathrm{mg} \mathrm{L}^{-1}\right)$ and $\mathrm{pH}=6.0$. For all experiments the temperature was kept constant at $25 \pm 2^{\circ} \mathrm{C}$. The UV lamp was turned on $30 \mathrm{~min}$ before the effluent was submitted to irradiation in order to reduce the variation of photon incidence due to the previous heating of the equipment.

\section{Results and discussion}

\subsection{The effect of concentration on direct photolysis}

The presence of different concentrations of IBU and TCS in liquid effluents justifies the need to understand the effect of this parameter on the degradation process.

The effect of the initial concentration of triclosan $\left(\mathrm{TCS}_{0}\right)$ and ibuprofen $\left(\mathrm{IBU}_{0}\right)$ on the photo-oxidation system is presented by Fig. 2, as a function of irradiation time. The experiments were developed using $2 \mathrm{~L}$ of synthetic effluent at $\mathrm{pH}=6.0$, a value adopted respecting the limits for discharge of effluents into water bodies according to Brazilian federal regulations (Conama 2005).

For ibuprofen (Fig. 2a), when in initial concentration ( $\left.\mathrm{IBU}_{0}=34.24 \pm 1.24 \mathrm{mg} \mathrm{L}^{-1}\right)$, the system showed an removal rate of $83.28 \%$ in 270 min with a remaining concentration of $5.73 \pm 0.16 \mathrm{mg} \mathrm{L}^{-1}$. The reduction of the initial concentration led to a reduction of the remaining concentration. In terms of degradation efficiency, the highest value was achieved by the system with $\mathrm{IBU}_{0}=24.77 \pm 0.51$, about $88.10 \%$. Overall, the average efficiency was $82.63 \%$ among all experiments. Wang et al. (2019) in $90 \mathrm{~min}$ of irradiation using a UV-LED system reported $51.58 \%$ degradation using an initial concentration of $41.25 \mathrm{mg} \mathrm{L}^{-1}$ in $8 \mathrm{~mL}$, a value lower than that obtained by this study.

The system was not greatly affected by the concentration of IBU for values lower than $34.24 \pm 1.24 \mathrm{mg}$

$169 \mathrm{~L}^{-1}$, where the difference between tests was $0.88 \pm 0.43 \mathrm{mg} \mathrm{L}^{-1}$, which was lower than the final difference of 3.63

$170 \pm 0.21 \mathrm{mg} \mathrm{L}^{-1}$ obtained between the experiment with higher and lower concentration, thus revealing some effect 171 on removal efficiency when high concentrations are used. Peng et al. (2017) attributed such behavior to the high 
172 presence of intermediates, which hinder the oxidation reactions of IBU. Wang et al. (2019), employing

173 concentrations of 41.26 - $103.14 \mathrm{mg} \mathrm{L}^{-1}$, showed that the photo-oxidation rate of IBU is directly proportional to

$174 \mathrm{IBU}_{0}$, going against the results suggested by this present study, where concentrations $\geq 34.24 \mathrm{mg} \mathrm{L}^{-1}$ affect the

175 removal efficiency of the direct UV photo-oxidation system.

176 TCS degradation (Fig. 2b) was not shown to be directly affected by TCS 0 up to $15.15 \pm 0.84 \mathrm{mg} \mathrm{L}^{-1}$, since

177 in $60 \mathrm{~min}$ of exposure, about $99.5 \%$ of the concentrations $\mathrm{TCS}_{0}=15.15 \pm 0.84 \mathrm{mg} \mathrm{L}^{-1}$ and $\mathrm{TCS}_{0}=8.89 \pm 0.83 \mathrm{mg}$

$178 \mathrm{~L}^{-1}$ were degraded. However, concentrations above these values are shown to affect the degradation system, similar

179 to the behavior exhibited by IBU. In the experiment with $\mathrm{TCS}_{0}=17.79 \pm 0.44 \mathrm{mg} \mathrm{L}^{-1}$, the degradation efficiency

180 was $87.12 \%$ in $60 \mathrm{~min}$, showing a remaining concentration of $2.29 \pm 0.01 \mathrm{mg} \mathrm{L}^{-1}$. Iovino et al. (2019), using a

181 direct photolysis system at pH 6.0 and concentrations of $4.48-17.89 \mathrm{mg} \mathrm{L}^{-1}$ in $100 \mathrm{~mL}$ concluded that $80 \%$ of the

182 initial concentration was degraded in the first $5 \mathrm{~min}$. Iovino et al. (2019), also reported a remaining concentration

183 of $0.049 \mathrm{mg} \mathrm{L}^{-1}$ when $\mathrm{TCS}_{0}=7.78 \mathrm{mg} \mathrm{L}^{-1}$ in a direct photolysis system after 60 min of irradiation in $100 \mathrm{~mL}$ of

184 solution. This value is lower than the one presented in this study, because when $\mathrm{TCS}_{0}=8.89 \pm 0.83 \mathrm{mg} \mathrm{L}^{-1}$ was

185 used, values below the detection limit were obtained after 40 min of irradiation.

a

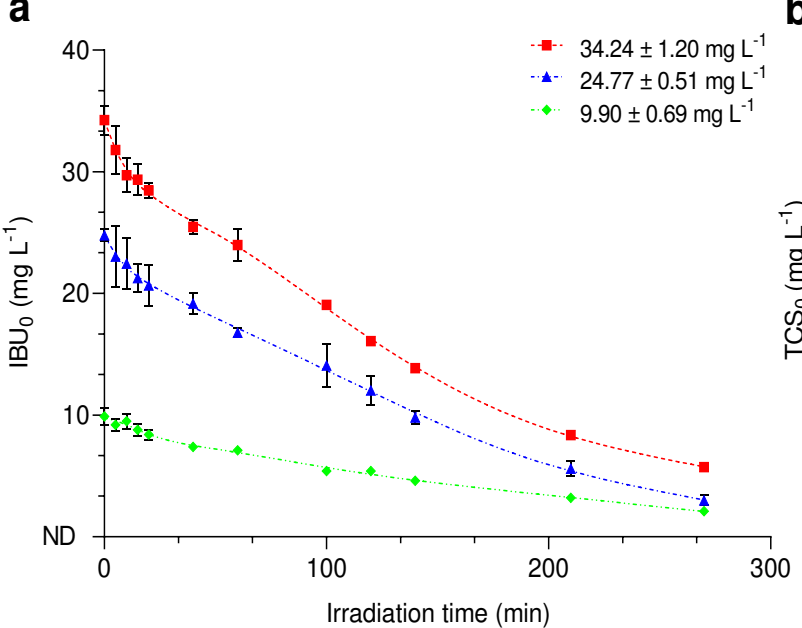

b

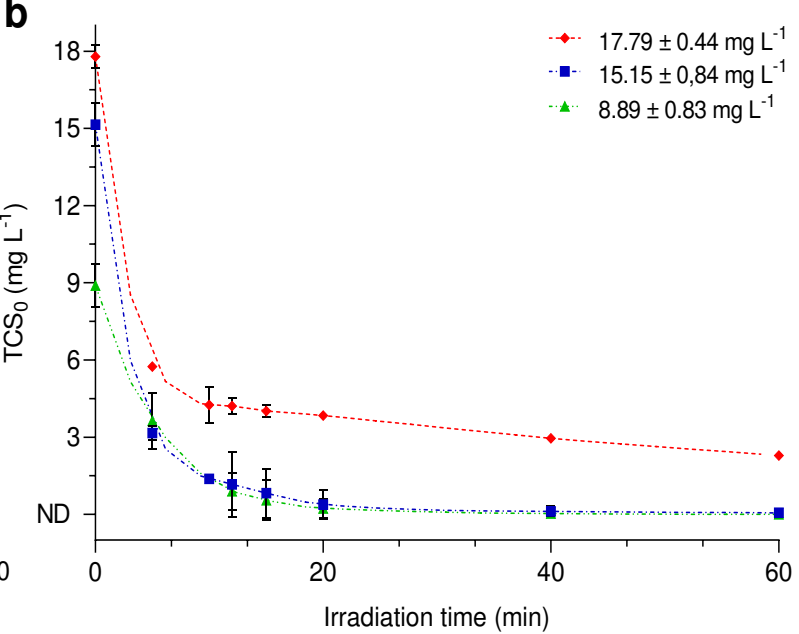

186
Fig. 1. The effect of initial concentration of (a) IBU and (b) TCS in synthetic effluent $\mathrm{pH}=6.0$ on oxidation by direct photolysis system.

\subsection{The effect of chemical speciation on direct photolysis}

The chemical speciation was evaluated by dissolving the contaminants in different $\mathrm{pH}$ ranges, respecting the $p \mathrm{Ka}$ of each target pollutant. In general, the molecular species is favored when $\mathrm{pH}<p \mathrm{Ka}$, as is the anionic species when $\mathrm{pH}>p \mathrm{Ka}$.

The $p \mathrm{Ka}=4.9$ (Pemberton and Hart 1999) and $p \mathrm{Ka}=7.9$ (Luo et al. 2018) values were used for TCS and IBU, respectively. The fractions of anionic $\left(\alpha^{-}\right)$and neutral $(\alpha)$ species of the target contaminants were determined according to Eq. (1) and Eq. (2), as proposed by Luo et al. (2018).

$$
\alpha=\frac{10^{-p H}}{10^{-p K a}+10^{-p H}}
$$




$$
\alpha^{-}=\frac{10^{-p K a}}{10^{-p K a}+10^{-p H}}
$$

a

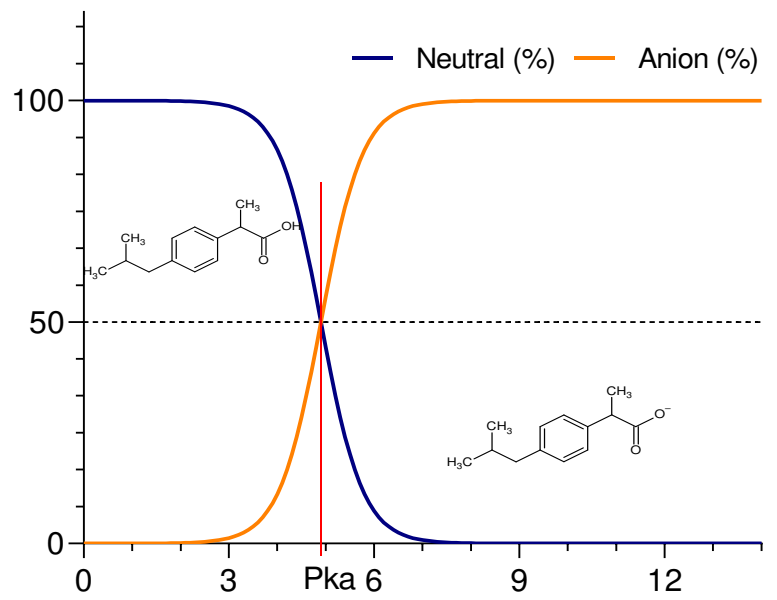

b

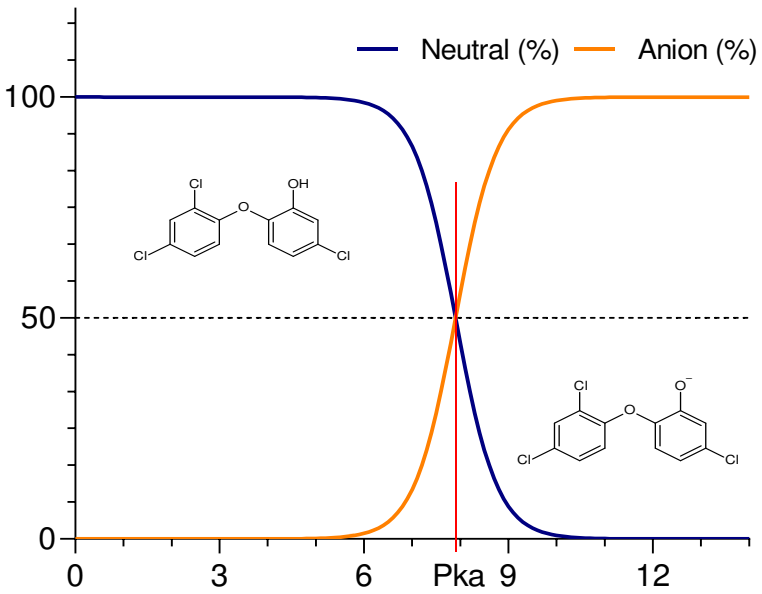

Fig. 3 Fraction of chemical species of (a) IBU and (b) TCS as a function of $\mathrm{pH}$ and $95.2 \%$ of the neutral species prevailed, respectively. For TCS, the experiments were performed at $\mathrm{pH}=9.4$ and 6.0 , and $96.93 \%$ of the anionic form $\left(\mathrm{TCS}^{-}\right)$and $98.76 \%$ of the neutral form prevailed, respectively.

The obtained data show a higher efficiency of IBU ${ }^{-}$degradation than IBU (Fig. 4a), with the contaminant being reduced by $83.2 \%$ in $270 \mathrm{~min}$ (Fig. 3a). Such results are in agreement with the values reported by Iovino et al. (2016), who observed the decrease of oxidation efficiency with decreasing $\mathrm{pH}$, obtaining the lowest oxidation values near $\mathrm{pH} 3$.

When compared to TCS, it is remarkable the greater difficulty of oxidation of the IBU molecule by the 212 UV system. Such behavior can be justified by the difference between the chemical structures of the contaminants.

213 The presence of certain functional groups such as phenol ( $\mathrm{Ar}-\mathrm{OH})$, weak $\mathrm{C}-\mathrm{H}$ bonds, and aryl chloride $(\mathrm{Ar}-\mathrm{Cl})$ in 214 the TCS molecule can facilitate photochemical reactions stimulated by the direct absorption of ultraviolet radiation 215 (Ahmad et al. 2016; Bartolomeu et al. 2018), while the IBU molecule presents only weak C-H bonds.

The oxidation of TCS using the direct photolysis system at $\mathrm{pH} 9.4$ proved to be much more efficient (Fig. 217 4b), obtaining pH $98.73 \%$ oxidation in $10 \mathrm{~min}$, and in $12 \mathrm{~min}$ the TCS concentration was already below the 218 detection level of the chromatograph. When the experiments took place at $\mathrm{pH} 6.0$, said result was only obtained 219 between 60 and $100 \mathrm{~min}$. The deprotonated form of TCS was shown to be more susceptible to degradation by 220 direct photolysis than its molecular form. The rapid oxidation of TCS at $\mathrm{pH}>9$, as reported by this study, is in line 221 with data obtained by Iovino et al. (2019), using a direct photolysis system in a $100 \mathrm{~mL}$ reactor at $\mathrm{pH} 10$, achieving nearly $99 \%$ removal in less than 30 min.

When compared to $\mathrm{pH} 6$, the anionic form of the TCS molecule was shown to be more efficient for degradation (Fig. 4b). It is suggestive to state that this process occurred due to the percentage of deprotonated 

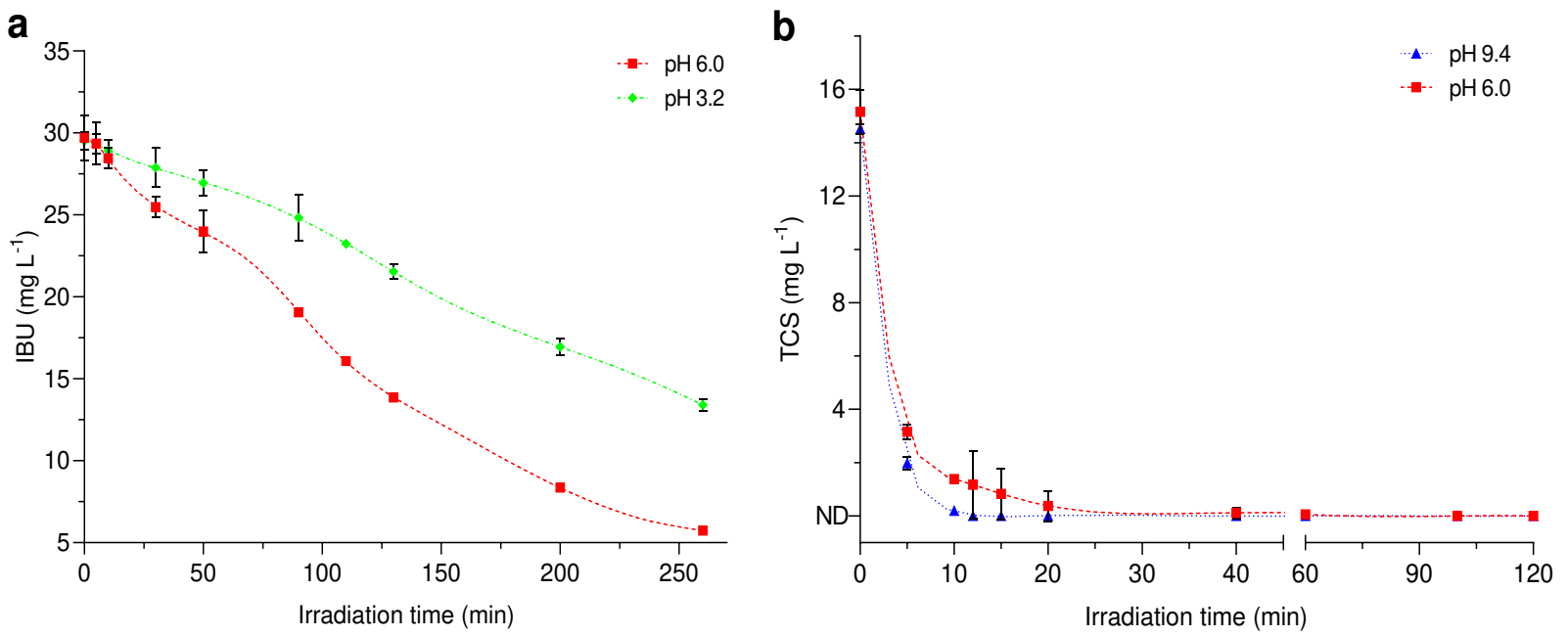

Fig. 4. The effect of chemical speciation on the temporal degradation of (a) IBU pH $=6.0$ and 3.2 and (b) TCS pH $=9.4$ and 6.0 in synthetic effluent by the direct UV photolysis system. $\mathrm{IBU}_{0}=29.61 \pm 0.59 \mathrm{mg} \mathrm{L}^{-1}, \mathrm{TCS}_{0}=15.10$

\subsection{The effect of $\mathrm{H}_{2} \mathrm{O}_{2}$ on the $\mathrm{UV} / \mathrm{H}_{2} \mathrm{O}_{2}$ system}

Photoassisted peroxidation was evaluated using different concentrations of $\mathrm{H}_{2} \mathrm{O}_{2}$ in synthetic effluent containing IBU and TCS at $\mathrm{pH}=6.0$ and room temperature $\left(25 \pm 2^{\circ} \mathrm{C}\right)$. Concentrations of 15,10 , and $5 \mathrm{mg} \mathrm{L}^{-1}$ of $\mathrm{H}_{2} \mathrm{O}_{2}$ were used. The use of $\mathrm{H}_{2} \mathrm{O}_{2}$ aims to increase the speed of degradation of the target contaminants through oxidation by ${ }^{\bullet} \mathrm{OH}$ radicals arising from photolytic cleavage of the $\mathrm{H}_{2} \mathrm{O}_{2}$ molecule (Eq. 3).

$$
\mathrm{H}_{2} \mathrm{O}_{2}+h v \rightarrow 2^{\bullet} \mathrm{OH}
$$

The hydroxyl radical is a strong, non-selective oxidizing agent that acts on the oxidation of organic and organometallic pollutants present in the solution, thus leading to their mineralization in the forms of inorganic ions, $\mathrm{H}_{2} \mathrm{O}$ or $\mathrm{CO}_{2}$ (Cuerda-Correa et al. 2020).

The low oxidation rate of IBU by the direct photolysis system justifies the use of $\mathrm{H}_{2} \mathrm{O}_{2}$ as an oxidizing agent, acting in tandem with $\mathrm{UV}$ radiation in the $\mathrm{UV} / \mathrm{H}_{2} \mathrm{O}_{2}$ system. The results show a reduction in the degradation

243 time of the contaminant when compared to the direct UV system at pH 6.0. The time reduction was 195 min when 244 using the lowest concentration of $\mathrm{H}_{2} \mathrm{O}_{2}\left(5 \mathrm{mg} \mathrm{L}^{-1}\right)$ and 225 min when using the highest concentration of $\mathrm{H}_{2} \mathrm{O}_{2}(15$ $\left.245 \mathrm{mg} \mathrm{L}^{-1}\right)$.

The highest efficiency for IBU oxidation was obtained when $10 \mathrm{mg} \mathrm{L}^{-1}$ of $\mathrm{H}_{2} \mathrm{O}_{2}$ was used, resulting in $97.39 \%$ oxidation of the contaminant after $75 \mathrm{~min}$ (Fig. 5a). The use of 15 and $5 \mathrm{mg} \mathrm{L}^{-1}$ of $\mathrm{H}_{2} \mathrm{O}_{2}$ resulted in $95.38 \%$ 248 and $82.32 \%$ oxidation, respectively. Peng et al. (2017) reported $82.4 \%$ removals of IBU in $30 \mathrm{~min} \mathrm{UV} / \mathrm{H}_{2} \mathrm{O}_{2} \mathrm{system}$ 249 when using $20 \mathrm{mg} \mathrm{L}^{-1}$ and $15 \mathrm{mg} \mathrm{L}^{-1}$ of IBU in $200 \mathrm{~mL}$ and $75 \mathrm{~W}$ lamp. In the present study, 30 min of irradiation and $34.5 \mathrm{mg} \mathrm{L}^{-1}$ of IBU obtained $72.03 \%$ oxidation of the target contaminant in the system with $15 \mathrm{mg} \mathrm{L}^{-1} \mathrm{of} \mathrm{H}_{2} \mathrm{O}_{2}$. 

did not prove to be the superior reactor among those used in this study. The results obtained for degradation of TCS by UV/ $\mathrm{H}_{2} \mathrm{O}_{2}$ showed that the efficiency is inversely related to the concentration of $\mathrm{H}_{2} \mathrm{O}_{2}$ used, with lower 254 concentrations being the source of higher oxidation rates. Using $5 \mathrm{mg} \mathrm{L}^{-1}$ of $\mathrm{H}_{2} \mathrm{O}_{2}$ degraded $97.69 \%$ of TCS in the synthetic effluent in $15 \mathrm{~min}$ and found below the detection limit between 15 and $30 \mathrm{~min}$ of irradiation. By increasing oxidant concentration, using 10 and $15 \mathrm{mg} \mathrm{L}^{-1}$ of $\mathrm{H}_{2} \mathrm{O}_{2}$, TCS was below the detection limit only between 30-60 min and between 60-75 min, respectively.

$\mathrm{H}_{2} \mathrm{O}_{2}$ was not shown to be fully decomposed by the system, and its residual was found in all treatments.

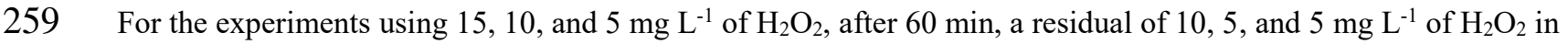

260 the synthetic effluent was still present. Liu et al. also reported a delay in $\mathrm{H}_{2} \mathrm{O}_{2}$ consumption in the $\mathrm{UV} / \mathrm{H}_{2} \mathrm{O}_{2}$ system, 261 being consumed by $20 \%$ after $10 \mathrm{~h}$ using $17 \mathrm{mg} \mathrm{L}^{-1}$ of $\mathrm{H}_{2} \mathrm{O}_{2}$ (Liu, Yiqing; He, Xuexiang; Fu, Yongsheng; Dionysiou 262 2016).
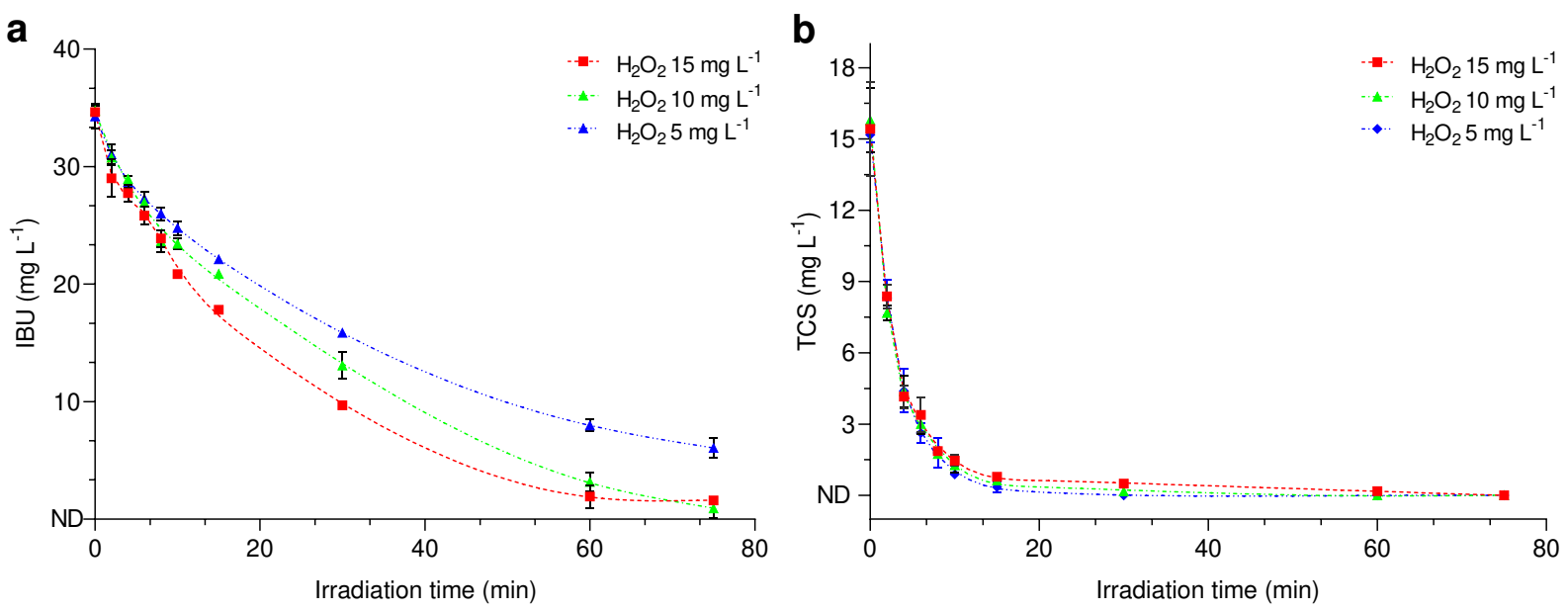

264 Fig. 5. The effect of the presence of $\mathrm{H}_{2} \mathrm{O}_{2}, 15,10$, and $5 \mathrm{mg} \mathrm{L}^{-1}$ on the temporal degradation of (a) IBU and (b) 265 TCS in synthetic effluent $\mathrm{pH}=6.0$ by the $\mathrm{UV} / \mathrm{H}_{2} \mathrm{O}_{2}$ system. $\mathrm{IBU}_{0}=34.5 \pm 0.25 \mathrm{mg} \mathrm{L}^{-1}, \mathrm{TCS}_{0}=15.46 \pm 0.31 \mathrm{mg}$ $266 \mathrm{~L}^{-1}$.

\subsection{Pseudo-first order kinetics and $t_{1 / 2}$}

The degradation kinetics were fitted to the pseudo-first order model. The pseudo-first order rate $\left(k^{\prime}, \min ^{-}\right.$

$$
-k^{\prime} t=\ln \left(\frac{C_{t}}{C_{0}}\right)
$$




$$
t_{1 / 2}=\frac{\ln 2}{k^{\prime}}
$$

Where $t_{1 / 2}$ is the degradation half-life (min) and $k^{\prime}$ is the pseudo-first order rate.

277 Figure 5 presents the degradation kinetic models of IBU and TCS fitted to the pseudo-first-order model

278 at different $\mathrm{pH}$ values $(\mathrm{pH}=3.6 ; 6.0 ; 9.4)$ and $\mathrm{H}_{2} \mathrm{O}_{2}$ concentrations $\left(5,10\right.$, and $\left.15 \mathrm{mg} \mathrm{L}^{-1} ; \mathrm{pH}=6.0\right)$ presenting as

279 a fixed parameter the initial concentration of the target contaminants. Table 3 lists the constants and degradation 280 half-lives of TCS and IBU.

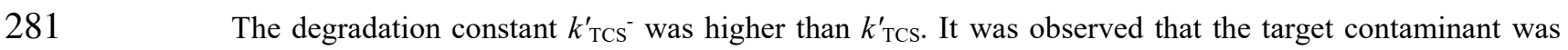
282 degraded faster when the $\mathrm{pH}$ values increased from 3.6 to 9.4 (Fig. 6b). For IBU the same behavior was observed 283 (Fig. 6a), where the degradation constant $k^{\prime}{ }_{\mathrm{IBU}}{ }^{-}$was higher than that obtained when the contaminant was in its 284 neutral molecular form. As the $\mathrm{pH}$ is increased, the neutral form deprotonates in solution, occurring the increase 285 of $k^{\prime}$ for IBU, as can be observed the values of the constants at $\mathrm{pH} 3.6,6.0$, and 9.4 (Table 2). This same behavior 286 was observed by Luo et al. (2018), in which the constant at $\mathrm{pH} 7.55$ was higher than that at $\mathrm{pH} 3.0$ in the degradation 287 of IBU by direct photolysis.

288 For TCS, the chemical speciation showed that the direct UV photolysis system at pH 9.4 is more efficient 289 in the photo-oxidation of the contaminant, which is confirmed by the obtained values of $k^{\prime}$ and $t_{1 / 2}$ (Table 2). 290 Azarpira et al. (2019) reported degradation constants of 0.131 and 0.0687 for TCS at concentrations of 7.5 and 


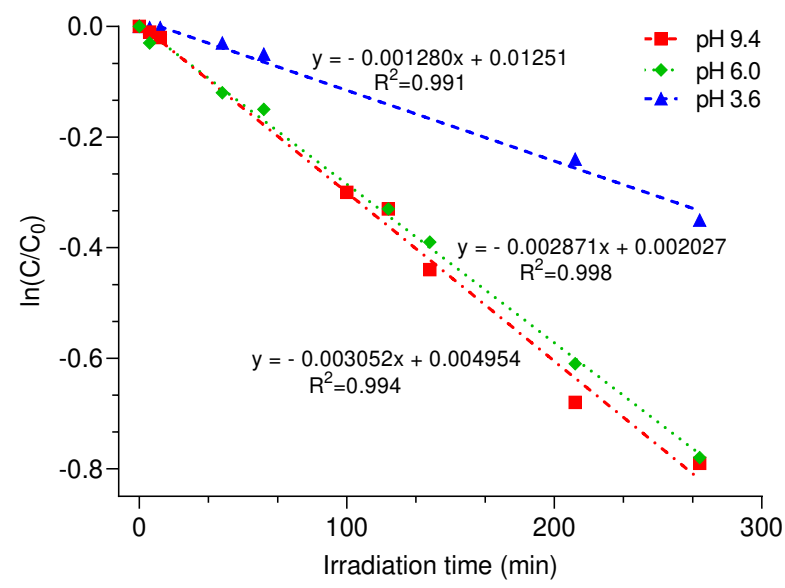

C

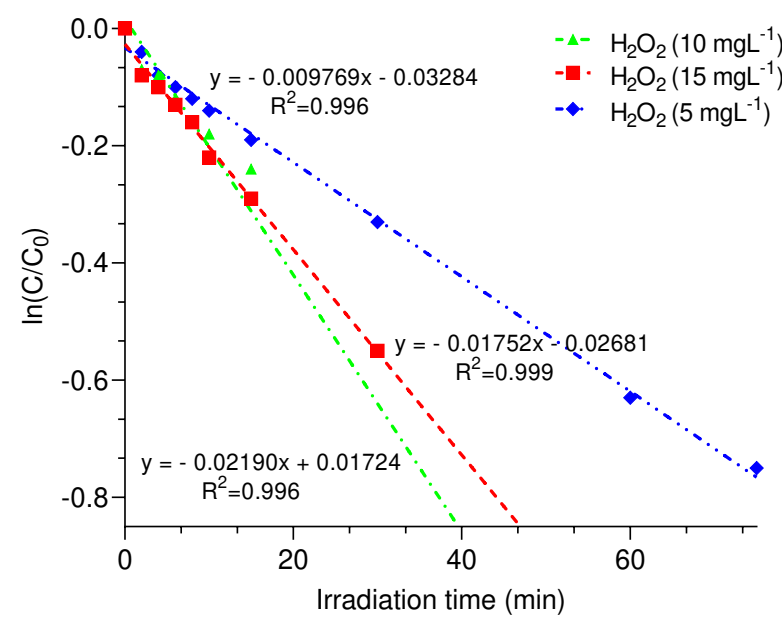

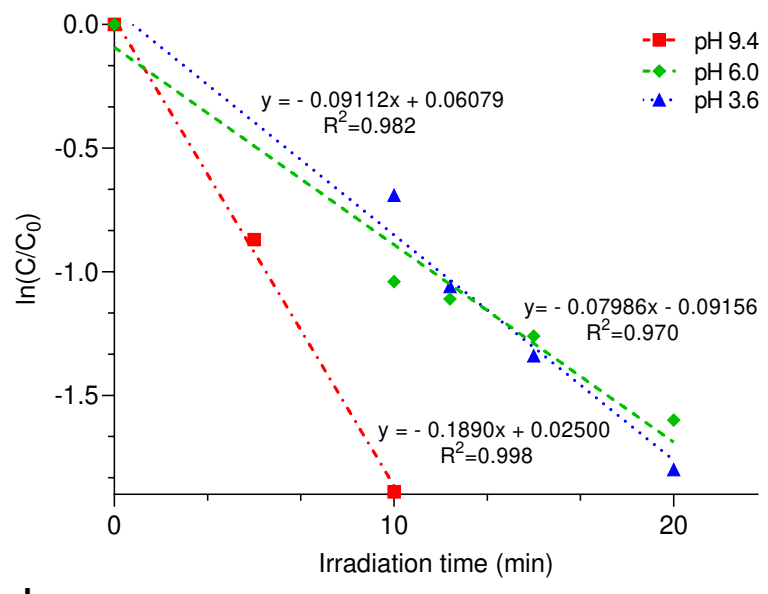

d

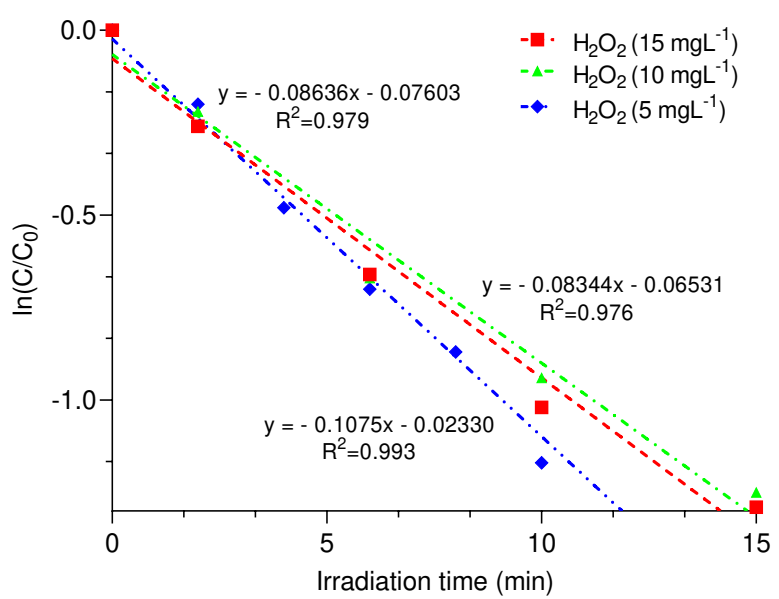

293 Fig. 6. Degradation kinetics by UV systems at $\mathrm{pH}=9.4,6.0$ and 3.6, for (a) IBU and (b) TCS and UV/H2O2 with $\left[\mathrm{H}_{2} \mathrm{O}_{2}\right]=15,10$ and $5 \mathrm{mg} \mathrm{L}^{-1}$ at $\mathrm{pH} 6.0$ for (c) IBU and (d) TCS. TCS $0=15.46 \pm 0.31 \mathrm{mg} \mathrm{L}^{-1}, \mathrm{IBU}_{0}=34.5 \pm 0.25$ $\mathrm{mg} \mathrm{L}^{-1}$. The lines represent the pseudo-first order model.

Sanchez-Prado et al. (2006), in a study on the photodegradation of TCS in domestic wastewater using UV and solar radiation, found that the $\mathrm{t}_{1 / 2}$ for degradation of the contaminant was $4.8 \mathrm{~min}$ at $\mathrm{pH}$ around 7 , with the pollutant being mostly in its molecular form. Such a result points to the reverse of that reported in this study, in which the contaminant in its molecular form $(\mathrm{pH} 6.0$ and 3.6) showed longer degradation half-lives both in the absence of $\mathrm{H}_{2} \mathrm{O}_{2}$ and in the presence of it (Table 2). This difference in results presented by Sanchez-Prado et al. (2006) can be explained by the use of a real matrix, where it is possible to occur the interference of different substances present in solution, and even the acceleration of degradation through organic matter, as reported by Iovino et al. (2019) using humic acids as a model compound of natural organic matter in the degradation of TCS by UV radiation.

The system used for IBU oxidation showed large degradation half-lives in the absence of $\mathrm{H}_{2} \mathrm{O}_{2}$ (Table 2). This may be related to the high concentration of IBU used. According to Peng et al. (2017), in an experiment using concentrations of $5-25 \mathrm{mg} \mathrm{L}^{-1}$ of IBU, increasing the concentration hindered the oxidation process, since the high 
309 concentration of IBU in solution also means the existence of high concentrations of intermediates. These

310 intermediates act as scavengers for $\mathrm{OH}$ radicals, reducing the reaction of the oxidant with IBU. Peng et al. further

311 concluded similar results to those presented by the present study, such as the difficulty of oxidation of IBU by UV

312 radiation alone (Peng et al. 2017).

313

314 Table 2. Pseudo-first order kinetic constants and half-lives of TCS and IBU in synthetic effluent in different UV 315 and $\mathrm{UV} / \mathrm{H}_{2} \mathrm{O}_{2}$ direct photolysis reactors. $\mathrm{TCS}_{0}=15.46 \pm 0.31 \mathrm{mg} \mathrm{L}^{-1}, \mathrm{IBU}_{0}=34.5 \pm 0.25 \mathrm{mg} \mathrm{L}^{-1}$.

\begin{tabular}{|c|c|c|c|c|c|c|}
\hline \multicolumn{3}{|l|}{ IBU } & \multicolumn{3}{|l|}{ TCS } & \multirow[t]{2}{*}{ Operational conditions } \\
\hline $\begin{array}{l}k^{\prime} \\
\left(\min ^{-1}\right)\end{array}$ & $\mathrm{R}^{2}$ & $\begin{array}{l}\mathrm{t}_{1 / 2} \\
(\min )\end{array}$ & $\begin{array}{l}k^{\prime} \\
\left(\min ^{-1}\right)\end{array}$ & $\mathrm{R}^{2}$ & $\begin{array}{l}\mathrm{t}_{1 / 2} \\
(\mathrm{~min})\end{array}$ & \\
\hline 0.0031 & 0.994 & 223.60 & 0.189 & 0.998 & 3.66 & Direct photolysis pH 9.4 \\
\hline 0.0029 & 0.998 & 239.01 & 0.0799 & 0.970 & 8.67 & Direct photolysis pH 6.0 \\
\hline 0.0013 & 0.991 & 533.19 & 0.0911 & 0.982 & 7.61 & Direct photolysis pH 3.6 \\
\hline 0.0175 & 0.999 & 39.61 & 0.0863 & 0.979 & 8.03 & $\mathrm{UV} / \mathrm{H}_{2} \mathrm{O}_{2}\left(15 \mathrm{mg} \mathrm{L}^{-1}\right) \mathrm{pH} 6.0$ \\
\hline 0.0219 & 0.996 & 31.65 & 0.0834 & 0.979 & 8.31 & $\mathrm{UV} / \mathrm{H}_{2} \mathrm{O}_{2}\left(10 \mathrm{mg} \mathrm{L}^{-1}\right) \mathrm{pH} 6.0$ \\
\hline 0.0097 & 0.996 & 71.46 & 0.108 & 0.993 & 6.42 & $\mathrm{UV} / \mathrm{H}_{2} \mathrm{O}_{2}\left(5 \mathrm{mg} \mathrm{L}^{-1}\right) \mathrm{pH} 6.0$ \\
\hline
\end{tabular}




\begin{tabular}{|c|c|c|c|c|c|}
\hline $\mathrm{TCS}_{0}\left(\mathrm{mg} \mathrm{L}^{-1}\right)$ & $\mathrm{IBU}_{0}\left(\mathrm{mg} \mathrm{L}^{-1}\right)$ & $k^{\prime}\left(\min ^{-1}\right)$ & $\mathrm{pH}$ & Operational conditions & Ref. \\
\hline 10.0 & 0 & 0.0687 & 7.0 & UIZ system; $11 \mathrm{~W}$ low pressure mercury lamp & (Azarpira et al. 2019) \\
\hline 7.5 & 0 & 0.1313 & 7.0 & & \\
\hline 5.0 & 0 & 0.1882 & 7.0 & & \\
\hline 7.8 & 0 & 0.302 & 6.0 & Direct photolysis; 5 tubes $8 \mathrm{~W}, \lambda=254 \mathrm{~nm}$ & (Iovino et al. 2019) \\
\hline 1.0 & 0 & 0.0045 & 7.0 & Direct photolysis; pure water; sunlight & (Qiao et al. 2014) \\
\hline 1.0 & 0 & 0.0019 & 9.0 & Direct photolysis; pure water; 500W xenon lamp & \\
\hline 1.0 & 0 & 0.0108 & 7.0 & Direct photolysis; pure water; 500W Hg lamp & \\
\hline 0 & 2.1 & 0.0043 & 3.0 & Direct photolysis; $10 \mathrm{~W}$ low-pressure Hg lamp; $\lambda=254 \mathrm{~nm}$ & (Luo et al. 2018) \\
\hline 0 & 2.1 & 0.0263 & 7.55 & & \\
\hline 0 & 15.0 & 0.0362 & 6.82 & $\mathrm{UV} / \mathrm{H}_{2} \mathrm{O}_{2} ; \mathrm{H} 2 \mathrm{O} 2=0.6 \mathrm{mM}$; pure water; $75 \mathrm{~W} \mathrm{Hg}$ lamp; $\lambda=254 \mathrm{~nm}$ & (Peng et al. 2017) \\
\hline 0 & 5.0 & 0.037 & - & Direct UV-C photolysis; pure water; three $9 \mathrm{~W}$ UV-C lamps; $\lambda=254 \mathrm{~nm}$ & (Da Silva et al. 2014) \\
\hline 0 & 5.0 & 0.001 & - & Direct UV-A photolysis; pure water; three UV-A 9W lamps; $\lambda=360 \mathrm{~nm}$ & \\
\hline 0 & 5.0 & 0.054 & - & $\mathrm{UV}-\mathrm{C} / \mathrm{TiO} 2 ; \mathrm{TiO} 2=120 \mathrm{mg} \mathrm{L}^{-1} ;$ pure water; three UV-C $9 \mathrm{~W}$ lamps; $\lambda=254 \mathrm{~nm}$ & \\
\hline
\end{tabular}




\subsection{Mineralization}

Despite the high oxidation rates of TCS and IBU obtained in this study, the results for TOC and COD showed that the contaminants were not entirely mineralized by the direct photolysis and $\mathrm{UV} / \mathrm{H}_{2} \mathrm{O}_{2}$ systems. For the multicomponent direct photolysis system, the highest mineralization rate obtained was $47.27 \%$ at $\mathrm{pH} 9.4$ after 270 min of irradiation time for TOC removal. In the UV/ $\mathrm{H}_{2} \mathrm{O}_{2}$ system, $10.97 \%$ TOC removal was obtained using 15 $\mathrm{mg} \mathrm{L}^{-1}$ of $\mathrm{H}_{2} \mathrm{O}_{2}$ in multicomponent solution after $75 \mathrm{~min}$. The substantial difference in oxidation may be directly related to the irradiation time and the $\mathrm{pH}$ of the solution. In more alkaline ranges the presence of anionic species facilitates the oxidation of IBU and TCS, and thus may enhance the mineralization of the contaminants.

The higher mineralization of contaminants by the direct UV system was also proven by the COD (Supplementary File). The experiments in $\mathrm{UV} / \mathrm{H}_{2} \mathrm{O}_{2}$ system occurred at $\mathrm{pH}=6.0$, where even though the IBU was mostly in anionic form, the system showed low removals of TOC, due to the very difficult oxidation of IBU, the competition for ${ }^{\bullet} \mathrm{OH}$ by the contaminants and the formation of intermediates. In $\mathrm{pH} 6.0$ system TCS obtained $40.63 \%$ of TOC removal after 75 min, while for IBU about $10.26 \%$ was obtained.

Trousil et al. (2018) also obtained low TOC removal values for IBU degradation, about $20.37 \%$ in direct photolysis system and $30.09 \%$ in UV/TiO2 system after $1 \mathrm{~h}$ irradiation. The removal of TOC in the oxidation of IBU may be related to the continuous formation of small carboxylic acids during the process (Szabó et al. 2011).

The low mineralization data point to byproduct formation from the oxidation of TCS and IBU by both the direct photolysis system and the UV/ $\mathrm{H}_{2} \mathrm{O}_{2}$ system. TCS has been known for its high rate of byproduct formation by phototransformation (Apell et al. 2020). Huang et al. (2018) draw attention to non-removal of byproduct cytotoxins by the UV and UV/H2O2 processes applied in the oxidation of TCS, even when reduction of the target contaminant concentration occurs, and increased UV fluence is required.

The main photolysis byproducts of IBU and TCS reported in the literature are shown in Fig. 7. For TCS, some byproducts formed are 2,8-dichlorodibenzo-p-dioxin (2,8-DCDD) arising from the skeletal rearrangement of the molecule, 2,4-dichlorophenol (DCP) formed from the cleavage of the ether (R-O-R), and 4'chlorophenoxyphenol (4'-CIPP) from hydrodechlorination (Kliegman et al. 2013; Apell et al. 2020), where due to the use of $\mathrm{MeOH}$ as a cosolvent, the formation of 2-phenoxyphenol (PP) is facilitated (Apell et al. 2020). For IBU, it has been widely reported that decarboxylation occurs (Szabó et al. 2011; Luo et al. 2018). Also, hydroxylation to the benzene ring under high energy absorptions is possible (Luo et al. 2018; Wang et al. 2021). Some byproducts are 1-ethyl-4-(2-methylpropyl)-benzene, 1-(4-isobutylphenyl)ethanol, and 4-isobutylacetophenone (Szabó et al.

a

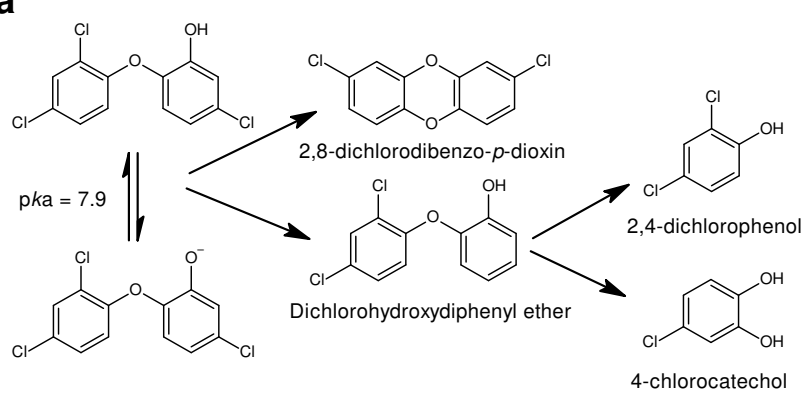

b

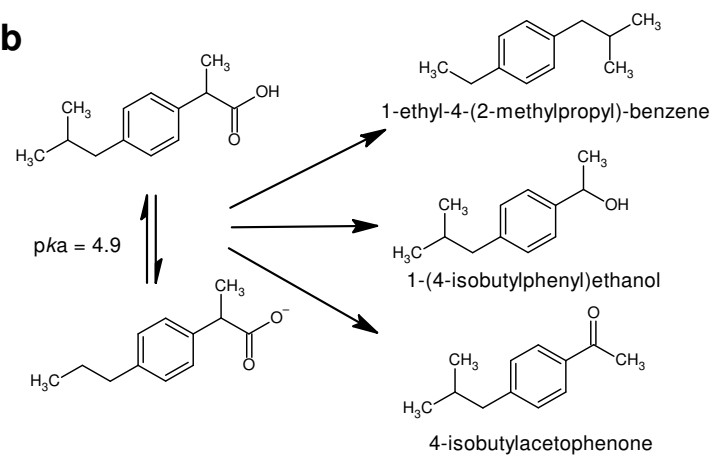

Fig. 7. Byproducts of degradation by direct photolysis proposed in the literature for (a) TCS (Kliegman et al. 2013; 


\subsection{Electric energy per order (EEO)}

The $\mathrm{E}_{\mathrm{EO}}$ is a parameter used to evaluate the amount of energy required for the decay of the target contaminant concentration by order of magnitude a $90 \%$ reduction in $1 \mathrm{~m}^{3}$ of water (Keen et al. 2018). The figure of merit was calculated according to Bolton et al. (2001) and is represented using Eq. (6) and fitted to pseudo-first order kinetic behavior (Eq. 7).

$$
E_{E O}=\frac{P \times t \times 1000}{V \times \log \left(C_{0} / C_{f}\right)}
$$

$$
E_{E O}=\frac{38.4 \times P}{V \times k^{\prime}}
$$

Where $\mathrm{E}_{\mathrm{EO}}$ is the electrical energy per order $\left(\mathrm{kWh} \mathrm{m}^{-3} \operatorname{order}^{-1}\right), \mathrm{P}$ is the lamp power $(\mathrm{kW}), t$ is the time required for degradation $(\mathrm{h}), \mathrm{V}$ is the solution volume (L), $\mathrm{C}_{0}$ and $\mathrm{C}_{f}$ are the initial and final contaminant concentrations $\left(\mathrm{mg} \mathrm{L}^{-1}\right)$, and $k^{\prime}$ is the pseudo-first order rate $\left(\mathrm{min}^{-1}\right)$.

Table 4 shows the $\mathrm{E}_{\mathrm{EO}}$ values obtained under different operating conditions of the photochemical reactors employed for the degradation of IBU and TCS in synthetic effluent at different $\mathrm{pH}$ values and $\mathrm{H}_{2} \mathrm{O}_{2}$ concentrations. The low energy required for TCS degradation compared to IBU is remarkable. The lower $\mathrm{E}_{\mathrm{EO}}$ values for TCS were already expected, since this contaminant proved to be more photosensitive than IBU.

The low $\mathrm{E}_{\mathrm{EO}}$ value found in the direct photolysis system at $\mathrm{pH} 9.4$ for TCS may be related to the wide presence of the $\mathrm{TCS}^{-}$species in the solution. As discussed earlier, photochemical transformations occur more easily on the deprotonated anionic form of this contaminant. Due to the high interaction of TCS with ultraviolet radiation, the chemical bonds are more susceptible to direct exposure and thus all of them can be broken (Azarpira et al. 2019).

The presence of $\mathrm{H}_{2} \mathrm{O}_{2}$ in the reactor did not significantly reduce the energy required for oxidation of TCS, with the chemical speciation of the contaminant being much more significant. The chemical speciation showed that the greater presence of deprotonated species reduced the amount of energy required by $51.77 \%$, when compared to $\mathrm{pH} 3.6$ where there is a majority of the molecular form of the target substance.

Azarpira et al. (2019), using a UV/Iodide/ZnO-based advanced oxidation system (UIZ) in a $150 \mathrm{~mL}$ tubular photochemical reactor and an $11 \mathrm{~W}$ power UV lamp achieved $E_{E O}$ values in range of $2.48-12.29 \mathrm{kWh} \mathrm{m}^{-3} \mathrm{order}^{-1}$ for TCS degradation between 1 and $10 \mathrm{mg} \mathrm{L}^{-1}$. These values reported by Azarpira et al. (2019) are lower than those developed by this present study, where in a larger volume of effluent, it was possible to reach lower amounts of energy required for TCS degradation, thus implying cost reduction for oxidation of such contaminants through a simpler system of operation, when compared to a tubular reactor, and without the need to use chemical catalysts.

For IBU degradation, the photochemical system showed the need of $\mathrm{H}_{2} \mathrm{O}_{2}$ for $\mathrm{E}_{\mathrm{EO}}$ reduction. IBU proved to be difficult to remove using the direct photolysis system, becoming more expensive when compared to TCS oxidation, requiring longer irradiation times and thus greater use of electricity. The use of $15 \mathrm{mg} \mathrm{L}^{-1}$ of $\mathrm{H}_{2} \mathrm{O}_{2}$ 
reduced the energy required for IBU degradation by $82.29 \%$. Although the use of $\mathrm{H}_{2} \mathrm{O}_{2}$ means implementing yet another cost to the system, the high reduction in energy use for degradation and the low concentration of $\mathrm{H}_{2} \mathrm{O}_{2}$ makes the cost of the oxidant less significant.

Trousil et al. reported $E_{\mathrm{EO}}$ of $136.2 \mathrm{kWh} \mathrm{dm}^{-3}$ using $11 \mathrm{~W}$ power UV lamp in a volume of $20 \mathrm{dm}^{-3}$ and a concentration of $20 \mathrm{mg} \mathrm{dm}^{-3}$ of IBU in a recirculating reactor. When using the $\mathrm{UV} / \mathrm{H}_{2} \mathrm{O}_{2}$ system with concentration of $0.5 \mathrm{~g} \mathrm{dm}^{-3}$ of oxidant, the energy required for degradation of $90 \%$ of the contaminant went to order of $61.2 \mathrm{kWh}$ $\mathrm{dm}^{-3}$, a 55.1\% reduction in energy consumption (Trousil et al. 2018).

Table 4. $E_{E O}$ required for degradation of IBU and TCS in synthetic effluent by direct photolysis and $\mathrm{UV} / \mathrm{H}_{2} \mathrm{O}_{2}$ systems. $\mathrm{TCS}_{0}=15.46 \pm 0.31 \mathrm{mg} \mathrm{L}^{-1}, \mathrm{IBU}_{0}=34.5 \pm 0.25 \mathrm{mg} \mathrm{L}^{-1}$

\begin{tabular}{|c|c|c|}
\hline IBU & TCS & Operational conditions \\
\hline $\mathrm{E}_{\mathrm{EO}}$ & $\mathrm{E}_{\mathrm{EO}}$ & \\
\hline$\left(\mathrm{kWh} \mathrm{m}^{-3}\right.$ order $\left.^{-1}\right)$ & $\left(\mathrm{kWh} \mathrm{m}^{-3}\right.$ order $\left.^{-1}\right)$ & \\
\hline 222.97 & 3.66 & Direct Photolysis pH 9.4 \\
\hline 238.34 & 8.06 & Direct Photolysis pH 6.0 \\
\hline 531.69 & 7.59 & Direct Photolysis pH 3.6 \\
\hline 39.50 & 8.01 & $\mathrm{UV} / \mathrm{H}_{2} \mathrm{O}_{2}\left(15 \mathrm{mg} \mathrm{L}^{-1}\right) \mathrm{pH} 6.0$ \\
\hline 31.56 & 8.28 & $\mathrm{UV} / \mathrm{H}_{2} \mathrm{O}_{2}\left(10 \mathrm{mg} \mathrm{L}^{-1}\right) \mathrm{pH} 6.0$ \\
\hline 71.26 & 6.40 & $\mathrm{UV} / \mathrm{H}_{2} \mathrm{O}_{2}\left(5 \mathrm{mg} \mathrm{L}^{-1}\right) \mathrm{pH} 6.0$ \\
\hline
\end{tabular}

\section{Conclusion}

In this study, the degradation of TCS and IBU was evaluated using two photochemical oxidation systems.

414 The processes in direct photolysis and $\mathrm{UV} / \mathrm{H}_{2} \mathrm{O}_{2}$ obtained favorable results for implementation as final polishing

415 technology, indicating the use of direct photolysis at $\mathrm{pH}=9.4$ for TCS oxidation and the increment of $\mathrm{H}_{2} \mathrm{O}_{2}$ for

416 IBU. The direct photolysis system at $\mathrm{pH} 9.4$ obtained values below the detection level of the chromatograph after

$41710 \mathrm{~min}$, the lowest $\mathrm{E}_{\mathrm{EO}}$, and the highest $k^{\prime}$ value, which was the best result obtained for TCS degradation. The

$418 \mathrm{UV} / \mathrm{H}_{2} \mathrm{O}_{2}$ system for oxidation of IBU reduced the $\mathrm{E}_{\mathrm{EO}}$ values and the time required for concentration decay. About

$41997.39 \%$ of the contaminant was oxidized when $10 \mathrm{mg} \mathrm{L}^{-1}$ of $\mathrm{H}_{2} \mathrm{O}_{2}$ was used in 75 min of irradiation. The results

420 point to incomplete mineralization of the target contaminants after both $\mathrm{UV}$ and $\mathrm{UV} / \mathrm{H}_{2} \mathrm{O}_{2}$ treatments. About

$42110.75 \%$ was mineralized in the reactor with $10 \mathrm{mg} \mathrm{L}^{-1}$ of $\mathrm{H}_{2} \mathrm{O}_{2}$ and $47.27 \%$ in direct $\mathrm{UV}$ photolysis reactor $\mathrm{pH} 9.4$,

422 thus proving the formation of degradation byproducts, which can lead to toxic substances.

\section{Declarations}

425 Funding: This work was supported by the Rio Grande do Sul State Research Support Foundation (FAPERGS) 426 (grant $n^{\circ} 368 /$ UFFS/2020)

427 Conflict of Interest: The authors declare that they have no conflict of interest.

\section{References}

429 Ahmad I, Ahmed S, Anwar Z, et al (2016) Photostability and Photostabilization of Drugs and Drug Products. Int $430 \quad$ J Photoenergy 2016:. https://doi.org/10.1155/2016/8135608 
Amos Sibeko P, Naicker D, Mdluli PS, Madikizela LM (2019) Naproxen, ibuprofen, and diclofenac residues in river water, sediments and Eichhornia crassipes of Mbokodweni river in South Africa: An initial screening. Environ Forensics 20:129-138. https://doi.org/10.1080/15275922.2019.1597780

Apell JN, Kliegman S, Solá-Gutiérrez C, McNeill K (2020) Linking Triclosan's Structural Features to Its Environmental Fate and Photoproducts. Environ Sci Technol 54:14432-14441. https://doi.org/10.1021/acs.est.0c05121

Arnold KE, Boxall ABA, Brown AR, et al (2013) Assessing the exposure risk and impacts of pharmaceuticals in the environment on individuals and ecosystems. Biol Lett 9:. https://doi.org/10.1098/rsbl.2013.0492

Azarpira H, Sadani M, Abtahi M, et al (2019) Photo-catalytic degradation of triclosan with UV/iodide/ZnO process: Performance, kinetic, degradation pathway, energy consumption and toxicology. J Photochem Photobiol A Chem 371:423-432. https://doi.org/10.1016/j.jphotochem.2018.10.041

Balakrishna K, Rath A, Praveenkumarreddy Y, et al (2017) A review of the occurrence of pharmaceuticals and personal care products in Indian water bodies. Ecotoxicol Environ Saf 137:113-120. https://doi.org/10.1016/j.ecoenv.2016.11.014

Bandala ER, Kruger BR, Cesarino I, et al (2021) Impacts of COVID-19 pandemic on the wastewater pathway into surface water: A review. Sci Total Environ 774:145586. https://doi.org/10.1016/j.scitotenv.2021.145586

Bartolomeu M, Neves MGPMS, Faustino MAF, Almeida A (2018) Wastewater chemical contaminants: remediation by advanced oxidation processes. Photochem Photobiol Sci 17:1573-1598. https://doi.org/10.1039/c8pp00249e

Bolton JR, Bircher KG, Tumas W, Tolman CA (2001) Figures-of-merit for the technical development and application of advanced oxidation technologies for both electric- and solar-driven systems. Pure Appl Chem 73:627-637. https://doi.org/10.1351/pac200173040627

Coha M, Farinelli G, Tiraferri A, et al (2021) Advanced oxidation processes in the removal of organic substances from produced water: Potential, configurations, and research needs. Chem Eng J 414:128668. https://doi.org/10.1016/j.cej.2021.128668

Conama (2005) Resolução CONAMA n ${ }^{\circ}$ 430/2011. http://www2.mma.gov.br/port/conama/legiabre.cfm?codlegi=646. Accessed 23 Jan 2018

Cuerda-Correa EM, Alexandre-Franco MF, Fernández-González C (2020) Advanced oxidation processes for the removal of antibiotics from water. An overview. Water (Switzerland) 12:. https://doi.org/10.3390/w12010102

Da Silva JCC, Teodoro JAR, Afonso RJDCF, et al (2014) Photolysis and photocatalysis of ibuprofen in aqueous medium: Characterization of by-products via liquid chromatography coupled to high-resolution mass spectrometry and assessment of their toxicities against Artemia Salina. J Mass Spectrom 49:145-153. https://doi.org/10.1002/jms.3320

Dhillon GS, Kaur S, Pulicharla R, et al (2015) Triclosan: Current status, occurrence, environmental risks and bioaccumulation potential. Int J Environ Res Public Health 12:5657-5684. https://doi.org/10.3390/ijerph120505657

Domingues E, Fernandes E, Gomes J, Martins RC (2021) Advanced oxidation processes perspective regarding swine wastewater treatment. Sci Total Environ 776:145958. 
https://doi.org/10.1016/j.scitotenv.2021.145958

472 Drury B, Scott J, Rosi-Marshall EJ, Kelly JJ (2013) Triclosan exposure increases triclosan resistance and

Espejo W, Celis JE, Chiang G, Bahamonde P (2020) Environment and COVID-19: Pollutants, impacts, dissemination, management and recommendations for facing future epidemic threats. Sci Total Environ 747:141314. https://doi.org/10.1016/j.scitotenv.2020.141314

Fang TH, Nan FH, Chin TS, Feng HM (2012) The occurrence and distribution of pharmaceutical compounds in the effluents of a major sewage treatment plant in Northern Taiwan and the receiving coastal waters. Mar Pollut Bull 64:1435-1444. https://doi.org/10.1016/j.marpolbul.2012.04.008

Farré, Marinel; Pérez, Sandra; Kantiani, Lina; Barceló D (2008) Fate and toxicity of emerging pollutants , their metabolites and transformation products in the aquatic environment. Trends Anal Chem 27:991-1007. https://doi.org/10.1016/j.trac.2008.09.010

Friuli V, Bruni G, Musitelli G, et al (2018) Influence of Dissolution Media and Presence of Alcohol on the In Vitro Performance of Pharmaceutical Products Containing an Insoluble Drug. J Pharm Sci 107:507-511. https://doi.org/10.1016/j.xphs.2017.06.001

Glaze WH, Kang JW, Chapin DH (1987) The chemistry of water treatment processes involving ozone, hydrogen peroxide and ultraviolet radiation. Ozone Sci Eng 9:335-352. https://doi.org/10.1080/01919518708552148

Gopalakrishnan S, Ghosh R, Renganathan T, Pushpavanam S (2021) Sensitive and selective determination of triclosan using visual spectroscopy. Spectrochim Acta - Part A Mol Biomol Spectrosc 254:119623. https://doi.org/10.1016/j.saa.2021.119623

Guidony NS, Scaini JLR, Oliveira MWB, et al (2021) ABC proteins activity and cytotoxicity in zebrafish hepatocytes exposed to triclosan. Environ Pollut 271:. https://doi.org/10.1016/j.envpol.2020.116368

Hersh E V., Dionne RA (2017) Nonopioid Analgesics, Seventh Ed. Elsevier

Huang Y, Liu Y, Kong M, et al (2018) Efficient degradation of cytotoxic contaminants of emerging concern by UV/H2O2. Environ Sci Water Res Technol 4:1272-1281. https://doi.org/10.1039/c8ew00290h

Iovino P, Chianese S, Canzano S, et al (2016) Ibuprofen photodegradation in aqueous solutions. Environ Sci Pollut Res 23:22993-23004. https://doi.org/10.1007/s11356-016-7339-0

Iovino P, Chianese S, Prisciandaro M, Musmarra D (2019) Triclosan photolysis: operating condition study and photo-oxidation pathway. Chem Eng J 377:121045. https://doi.org/10.1016/j.cej.2019.02.132

Jamerson BD, Haryadi TH (2020) The use of ibuprofen to treat fever in COVID-19: A possible indirect association with worse outcome? Med Hypotheses 144:109880. https://doi.org/10.1016/j.mehy.2020.109880

Keen O, Bolton J, Litter M, et al (2018) Standard reporting of Electrical Energy per Order (E $E_{\mathrm{EO}}$ ) for UV/ $\mathrm{H}_{2} \mathrm{O}_{2}$ reactors (IUPAC Technical Report). Pure Appl Chem 90:1487-1499

Kermia AEB, Fouial-Djebbar D, Trari M (2016) Occurrence, fate and removal efficiencies of pharmaceuticals in wastewater treatment plants (WWTPs) discharging in the coastal environment of Algiers. Comptes Rendus Chim 19:963-970. https://doi.org/10.1016/j.crci.2016.05.005

Khatikarn J, Satapornvanit K, Price OR, Van den Brink PJ (2018) Effects of triclosan on aquatic invertebrates in tropics and the influence of pH on its toxicity on microalgae. Environ Sci Pollut Res 25:13244-13253. 
https://doi.org/10.1007/s11356-016-7302-0

512 Kliegman S, Eustis SN, Arnold WA, McNeill K (2013) Experimental and theoretical insights into the

513 involvement of radicals in triclosan phototransformation. Environ Sci Technol 47:6756-6763.

514 https://doi.org/10.1021/es3041797

515 Liu, Yiqing; He, Xuexiang; Fu, Yongsheng; Dionysiou D (2016) Degradation kinetics and mechanism of oxytetracycline by hydroxyl radical-based advanced oxidation processes. Chem Eng J 284:1317-1327. https://doi.org/https://doi.org/10.1016/j.cej.2015.09.034

Liu J, Ye J, Chen Y, et al (2018) UV-driven hydroxyl radical oxidation of tris(2-chloroethyl) phosphate: Intermediate products and residual toxicity. Chemosphere 190:225-233. https://doi.org/10.1016/j.chemosphere.2017.09.111

Lu H, Ma H, Tao G (2009) Spectrophotometric determination of triclosan in personal care products. Spectrochim Acta - Part A Mol Biomol Spectrosc 73:854-857. https://doi.org/10.1016/j.saa.2009.04.007

Luo S, Wei Z, Spinney R, et al (2018) UV direct photolysis of sulfamethoxazole and ibuprofen: An experimental and modelling study. J Hazard Mater 343:132-139. https://doi.org/10.1016/j.jhazmat.2017.09.019

Mohan S, Balakrishnan P (2019) Triclosan in Treated Wastewater from a City Wastewater Treatment Plant and its Environmental Risk Assessment. Water Air Soil Pollut 230:. https://doi.org/10.1007/s11270-019-40989

Pemberton RM, Hart JP (1999) Electrochemical behaviour of triclosan at a screen-printed carbon electrode and its voltammetric determination in toothpaste and mouthrinse products. Anal Chim Acta 390:107-115. https://doi.org/10.1016/S0003-2670(99)00194-4

Peng M, Li H, Kang X, et al (2017) Photo-degradation ibuprofen by UV/H2O2 process: response surface analysis and degradation mechanism. Water Sci Technol 75:1-18. https://doi.org/10.2166/wst.2017.149

Qiao X, Zheng X, Xie Q, et al (2014) Faster photodegradation rate and higher dioxin yield of triclosan induced by cationic surfactant CTAB. J Hazard Mater 275:210-214. https://doi.org/10.1016/j.jhazmat.2014.05.012

Rede D, Santos LHMLM, Ramos S, et al (2019) Individual and mixture toxicity evaluation of three pharmaceuticals to the germination and growth of Lactuca sativa seeds. Sci Total Environ 673:102-109. https://doi.org/10.1016/j.scitotenv.2019.03.432

Sanchez-Prado L, Llompart M, Lores M, et al (2006) Monitoring the photochemical degradation of triclosan in wastewater by UV light and sunlight using solid-phase microextraction. Chemosphere 65:1338-1347. https://doi.org/10.1016/j.chemosphere.2006.04.025

Szabó RK, Megyeri CS, Illés E, et al (2011) Phototransformation of ibuprofen and ketoprofen in aqueous solutions. Chemosphere 84:1658-1663. https://doi.org/10.1016/j.chemosphere.2011.05.012

Tan C, Jian X, Su L, et al (2021) Kinetic removal of acetaminophen and phenacetin during LED-UV365 photolysis of persulfate system: Reactive oxygen species generation. Chemosphere 269:. https://doi.org/10.1016/j.chemosphere.2020.129337

Trousil V, Palarcik J, Blazkova Z, et al (2018) Paracetamol and ibuprofen removal from aqueous solutions by ozonation and photochemical processes. Environ Prot Eng 44:159-175. https://doi.org/10.5277/epe180411

Wang P, Bu L, Wu Y, et al (2021) Mechanistic insight into the degradation of ibuprofen in UV/H2O2 process via a combined experimental and DFT study. Chemosphere 267:128883. https://doi.org/10.1016/j.chemosphere.2020.128883 
551 Wang Q, Su M (2020) A preliminary assessment of the impact of COVID-19 on environment - A case study of 552 China. Sci Total Environ 728:138915. https://doi.org/10.1016/j.scitotenv.2020.138915

553 Wang Z, Srivastava V, Ambat I, et al (2019) Degradation of Ibuprofen by UV-LED/catalytic advanced oxidation 554 process. J Water Process Eng 31:100808. https://doi.org/10.1016/j.jwpe.2019.100808

555 Yang GCC, Tsai HJ, Chang FK (2015) Occurrence of triclosan in the tropical rivers receiving the effluents from the hospital wastewater treatment plant. Environ Monit Assess 187:. https://doi.org/10.1007/s10661-0154372-2

Yunus AP, Masago Y, Hijioka Y (2020) COVID-19 and surface water quality: Improved lake water quality 
566

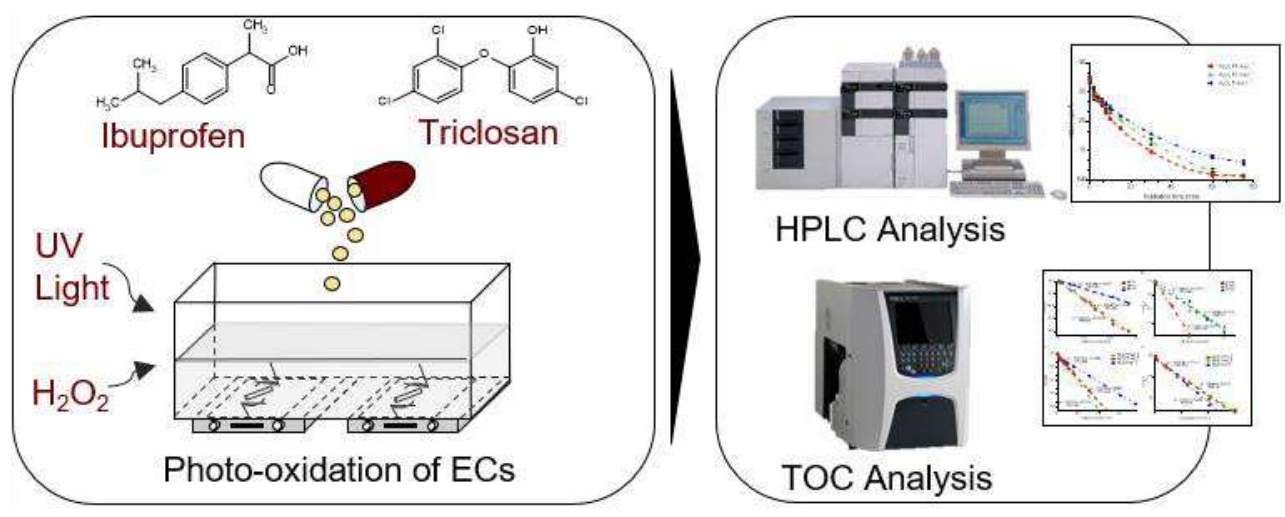




\section{Supplementary Files}

This is a list of supplementary files associated with this preprint. Click to download.

- ElectronicSupplementaryMaterialESPR.docx 